\title{
Business Strategy as a Mediation of Management Capabilities and Entrepreneurial Orientation in Business Performance
}

\author{
Giriati* \\ Faculty of Economics and Business, University of Tanjungpura, Pontianak, West Kalimantan, Indonesia.
}

\begin{abstract}
Objective - This article aims to analyze the influence of mediating Business Strategy variables on Management Capabilities (MC) and Entrepreneurial Orientation (EO) toward Business Performance.

Methodology/Technique - This study was conducted on group of students of Economics and Business Department who practiced as entrepreneurs, using Path Analysis (Amos, 18.0).

Findings - The results of the analysis show that the management capabilities do not support the indirect influence of business strategies on business performance. However, entrepreneurial orientation supports the indirect influence of business strategies on business performance. Meanwhile, management capabilities have a significant direct effect on business performance.

Novelty - Without going through a business strategy, entrepreneurial orientation does not have a significant direct effect on business performance, because business strategy supports business performance or direct influence.
\end{abstract}

Type of Paper: Empirical

JEL Classification: M16, M21, M29.

Keywords: Business Strategy; Management Capabilities; Entrepreneurial Orientation; Business Performance.

\section{Introduction}

The current state of globalization with all its consequences cannot be stopped. This has led to cooperation between countries in the fields of economics, politics, defense and security which has created businesses that cannot be managed in the usual way. On the one hand, this condition presents an opportunity for Indonesia to have the chance to penetrate new markets however on the other hand, it also poses a threat to its competitors. In particular, the economic integration of ASEAN countries through the establishment of the 2015 ASEAN Economic Community (MEA) has provided space for the Indonesian business world allowing Indonesian products to compete in the international market.

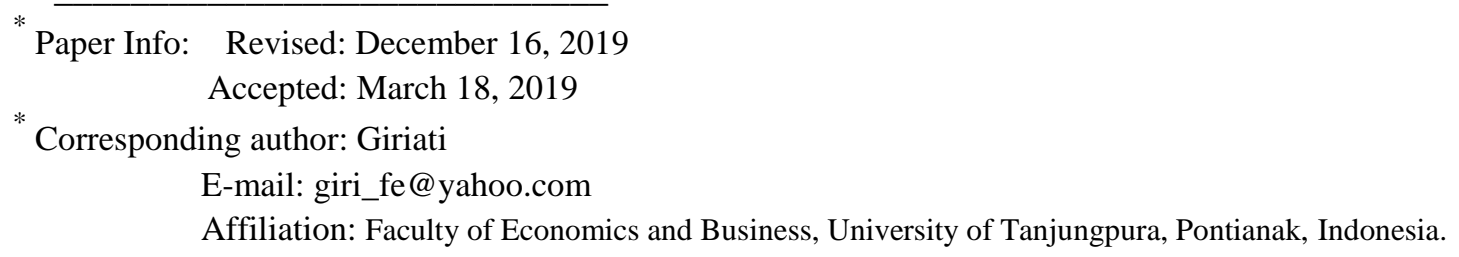


On the contrary, if Indonesia does not have superior competitiveness, Indonesia will become an industrial market that is only able to accommodate other ASEAN countries. Competitive advantage is largely determined by the competencies possessed by the industry and the entrepreneurial community, including both soft skills and hard skills as well as an optimistic attitude in facing global competition. To emphasize, Indonesia needs entrepreneurs to face the MEA. Indonesia has its own strengths, such as having economic potential derived from natural resources, population and cultural diversity making Indonesia more attractive, entrepreneurs that play an important role in supporting the economy of a country. Thus far, entrepreneurs in Indonesia account for only $1.6 \%$ of the population. Meanwhile, to develop an advanced economy, a country requires a minimum of $2 \%$, or in the case of Indonesia, 4.8 million entrepreneurs (McCleiland, 2011). In comparison, Singapore has $7.2 \%$ entrepreneurship, Malaysia $2.1 \%$, Thailand $4.1 \%$, South Korea $4.0 \%$ and the United States $11.5 \%$.

Thus, the government, educational institutions, and entrepreneurs themselves need to play an active role to encourage the creation and development of innovative, competitive and sustainable entrepreneurs, particularly through the participation of educational institutions. Entrepreneurs have a complex and multidimensional task, including a number of skills used to regulate the organization across three categories: conceptual, humanitarian, and technical (Daft, 2002). Additionally, risk and rationalization in decision making have an impact on yield (Allesandri, 2008; Nooraie, 2008). Ramo (2009) states that an emotional influence and social skills also have an impact on productivity. Furthermore, Surachman (2007) claims that management capabilities have an impact on risk and product development.

According to Garcia, organizational innovation and organizational learning together encourage entrepreneurs to increase the competitiveness of their business (2007). Suci (2009) argues that management capability has a positive and significant impact on SME performance. In other words, good management capabilities will improve business performance (Latif, 2002). Hence, organizational ability has important consequences on business performance in achieving a sustainable competitive advantage.

The impact resulting from the ability to manage a sustainable competitive advantage has attracted the interest of many researchers (Ulrich, 1987, 1989; Stalk et. al., 1992; Hall, 1993; Day, 1994). According to Latief (2002), competitiveness is the main objective, and management must have the confidence to effectively encourage leadership behavior in the areas of planning, organizing, coordinating, giving orders and supervision. Competitiveness is an internal source that not only involves assets, but also involves employees who must be managed and organized properly (Ulrich \& Lake, 1991). For this reason, managers must be able to manage processes and determine the best practices. The development of organizational capabilities also depends very much on the response of the top management of the company to changes in the environment that are full of uncertainties, which will eventually have an impact on the company's performance. Additionally, the success of an organization is influenced by the capabilities of management both individually and as a group, and its ability to manage changes and current business to achieve sustainable growth (Rogers, 2004). Therefore, complex economic and technological changes must be taken seriously.

\section{Literature Review}

\subsection{Management Capabilities}

Organizational capability based on a resource-based theoretical approach is one of the important internal factors in managing the existing resources owned by a company so that the company can achieve a competitive advantage (Wernerfelt, 1984; Barney, 1991, 1995; Peteraf, 1993; Teece et. al., 1997). When the capabilities in the company are good, the management of resources will be good as well. The ability of management is a broader concept than competence, because it includes a strategy and links management capabilities with resources. Capabilities and competencies are displayed in technical areas and social problems of both individuals and the organization. Grant (1991) defines ability as a complex pattern of 
coordination between people and resources learned through continuous repetition. The resource-based view (RBV) explains that, in creating a sustainable competitive advantage, a company must be able to create value for customers and organizations that must be rare and difficult for competitors to emulate (Barney, 1991; 1995). Management capabilities include knowledge, attitude and skills. (Porter \& Kettels, 2003; Cockerill, 1993). Thus, competitive advantage has an impact on company performance (Ulrich, 1987).

\subsection{Entrepreneurial Orientation}

Entrepreneurship Orientation (EO) involves the process of making strategies and practicing entrepreneurship (Rauch, Wiklund, Lumpkin \& Frese, 2009, p. 763). Entrepreneurial orientation helps companies see opportunities and identify trends in consumer needs by making product innovations, and finding the confidence to make brave decisions. The term entrepreneurship is generally associated with the creation of value and wealth, as well as the ability to see opportunities and create jobs (Morris et. al., 2008). Further, Stevenson and Jarillo-Mossi (1986) state that entrepreneurship is the process of creating value by bringing together unique resources to exploit opportunities. Thus, this EO definition is consistent with the view that EO leads to entering new or existing markets through product or service innovation, and is bold to take risks to make decisions. There have been many relationships between $\mathrm{EO}$ and business performance, yet its relationship with business performance is still unsettled in the research. According to Rauch et. al. (2009), there is a positive relationship between EO and business performance.

\subsection{Business Strategy}

The role of entrepreneurships in small and medium enterprises is undoubted; there are many things learned in the fields related to business strategy and innovation (Hitt et. al., 2001). The SME business strategy concerns the appropriateness of internal management capabilities and the company's response to the external environment. Thus, companies must compete using strategic decisions such as new products in previous markets, production of certain market niches, certain segments and making changes to product characteristics (Suryana, 2003). Similarly, the results of Suci's study (2009) indicate that business strategies have a positive and significant influence on business performance. Contrary to this, Suci's statements are not consistent with research by Miller (1987) and Hopkins (1997) who believe that business strategies have nothing to do with business performance.

\subsection{Business Performance}

The findings of research on RBV state that business performance results from the implementation of strategies that are relevant to the resources owned and the existing external environment. The speed of adaptation to environmental changes will determine a sustainable competitive advantage, and some indicators can be used to measure business performance such as sales growth, asset growth, profit growth and workforce growth. Therefore, from a theoretical discussion, the conceptual framework can be described as follows:

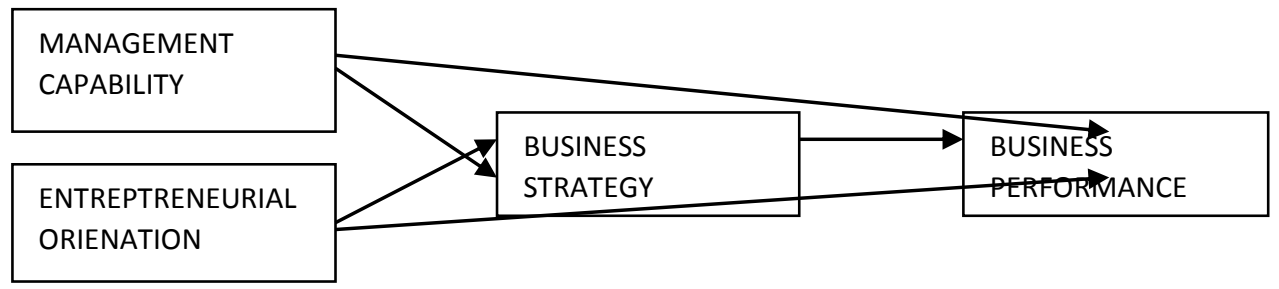

Figure 1. Conceptual Framework 


\subsection{Research Hypothesis}

The hypotheses of the research are as follows:

H1. Management ability significantly influences the business strategy of entrepreneurial student groups.

H2. Entrepreneurial orientation significantly influences the business strategy of entrepreneurial student groups.

H3. Management ability significantly influences the business performance of entrepreneurial student groups.

H4. Entrepreneurial orientation significantly influences the business performance of entrepreneurial student groups.

H5. Business strategies significantly influence the business performance of entrepreneurial student groups.

\section{Research Methodology}

This study employs a quantitative method and the primary data collection was conducting by distributing questionnaires with both open and close-ended questions to groups of students who practiced becoming entrepreneurs using a Likert scale. The data obtained was analyzed using Path analysis with the Amos 18.0 program (Ghozali, 2011). The population in this study consisted of 64 students who were trained as entrepreneurs. The sample was determined based on the census method which was also the entire population of this research.

\section{Results}

\subsection{Hypothesis Testing}

Evaluation of the accuracy of the model was done when the model was estimated using Amos. The evaluation of assumption of normality shows that all variables are normally distributed (CR table). There was no occurrence of multicollinearity and singularity which were indicated by the matrix covariance value. A complete evaluation is displayed in Table 1 below.

Table 1. Direct and Indirect Effect

\begin{tabular}{|c|c|c|c|c|c|c|}
\hline NO & IND VAR & DEP VAR & \multicolumn{3}{|c|}{ DIRECT } & EFFECT \\
\cline { 4 - 7 } & & & Standardized & CR & p-value & Details \\
\hline HIP 1 & Mg Capabilities & $\begin{array}{c}\text { Bus } \\
\text { Strategy }\end{array}$ & 0,054 & 0.679 & 0.346 & In-sig \\
\hline HIP 2 & Entrepreneurial Ort & $\begin{array}{c}\text { Bus } \\
\text { Strategy }\end{array}$ & 0,227 & 1.876 & 0.045 & Sig \\
\hline HIP 3 & Mg Capabilities & $\begin{array}{c}\text { Bus } \\
\text { Perform }\end{array}$ & 0.217 & 2.225 & 0.012 & Sig \\
\hline HIP 4 & Entrepreneurial Ort & $\begin{array}{c}\text { Bus } \\
\text { Perform }\end{array}$ & 0.018 & 0.121 & 0.794 & In-sig \\
\hline HIP 5 & Bus Strategy & $\begin{array}{c}\text { Bus } \\
\text { Perform }\end{array}$ & 0.497 & 4.467 & 0.004 & Sig \\
\hline IND & EFFECT & & & & Details \\
\hline
\end{tabular}




\begin{tabular}{|c|c|c|c|c|}
\hline & & VAR & & \\
\hline Mg Capabilities & $\begin{array}{c}\text { Bus } \\
\text { Perform }\end{array}$ & Bus Strategy & 0.005 & In-sig \\
\hline Entrepreneurial Ort & $\begin{array}{c}\text { Bus } \\
\text { Perform }\end{array}$ & Bus Strategy & 0.112 & Sig \\
\hline
\end{tabular}

Source: Processed data 2018

Based on Table 1, the proof of the hypothesis can be explained by comparing the P-value and the standardized value. The results of the hypothesis testing can be explained as follows:

Hypothesis 1: management capabilities do not support the indirect influence of business strategies on business performance.

Hypothesis 2: entrepreneurial orientation supports the indirect influence of business strategies on business performance.

Hypothesis 3: management ability has a significant direct effect on business performance, without going through a business strategy.

Hypothesis 4: entrepreneurial orientation does not have a significant direct effect on business performance, but through a business strategy.

Hypothesis 5: business strategies support business performance or direct influence.

\section{Discussion}

This paper aims to investigate the effect of management capability and entrepreneurial orientation on business performance in groups of students who practiced as entrepreneurs. For this purpose, the author collected the research data in 2017 to see observe the development of the students' practice and to test the impact of management capabilities and EOs mediated by business strategies on business performance. The skills that are associated with proactive EO for uncertainty management include innovation to meet opportunities and threats that arise, anticipation of market direction and tolerance to risks.

Management capabilities include business skills and technical skills, a good attitude and ability to develop business plans and make decisions. The ability to determine strategy options must also be carried out carefully considering the effects of their interactions on business performance. EO is sometimes associated with the environment and some studies explain that proactiveness is not directly related to performance, but it is related to environmental interactions (Covin \& Slevin, 1989). Thus, the level of EO must be related to the operational environment of the company. Companies where the EO level is not in accordance with the level of environmental turbulence and business risk will result in lower business performance. The proactive, innovative and risk-taking nature will look wise in uncertain environmental conditions and must be full of caution. In line with the results of Hughes and Morgan (2007), from their study of British companies, it would appear to be more proactive in the role that EO plays in driving company performance. Thus, management ability is highly dependent on knowledge and skills in managing resources owned in accordance with the RBV model (Penrose, 1984; Barney, 1991) and determining competing strategies in the market.

\section{Conclusion}

Further research should include additional variables or use control variables to determine business performance, particularly for students who practice as entrepreneurs. Further research should also use the SME model that is applied in other disciplines which is relevant for students who practice as entrepreneurs. 
In addition, the study of small and medium enterprises often involves strategies and management capabilities in improving performance. Therefore, a more in-depth study of entrepreneurial strategies applied to small and medium-sized enterprises is recommended.

\section{References}

Allesandri, Tood. M (2008). Risk and Procedural rationality, A Behavioral Theory Perspective, Journal of strategy and Management, 1 (2), 196-217

Barney.J.B\& Arikan ,A,M.(2001). The Resource- Based View; origin and implication. The Blackwell handbook of Strategic Managemet, 716

Cockerill.A.P, (1993). Validation Study into the High Performance Managerial Competencies, London Business School.

Covin,J.G, \& Slevin,D.P,(1989). Startegic Management of Small Firmin Hostile and Benign Environment, Strategic Management Journal Jan/Feb, 10 (1).

Daft.R.L,(2002). Organization Theory and Design, 5th Ed. West Publishing Company. St Paul.MN.

Ghozali, Imam (2011). Structural Equation Models Concept and Application with AMOS19.0 program. Publisher : Board Publisher Diponegoro University in Semarang

Grant,R.M, (1991). The Resource based Theory of Competitive Advantage : Implication for Strategy Formulation. California Management Review. Spring : 114-135.

Garcia, Victor,J, (2007). Antecedent and Consiquencies of Organizational Innovation and Organizational Learning in Entrepreneurship, Journal Management \& Data System,106 (1),21-42

Hitt, Michael,A.R.Duane Ireland,\& Robert E.Hoskinson. (2001). Strategic Management: Competitive and Globalization, Fourth Edition South-Western Publishing, USA.

Hopkins \& Hopkins,(1997). Strategic Planning-Financial Performance Relationship in Bank, A Causal Examinations, Strategic Management Journal, 18(8), 635-652

Hall,R.(1993). A Frame Linking Intangible Resource and Capabilities to Sustainable Competitive Advantage, Strategic Management Journal.14(8) : 607-618.

Latif, Dafiz.A (2002). Model for Teaching the Management Skills Component of Managerial Effectiveness to Pharmacy Student. Review,377.

Miller.D,\& Friesen,P. (1987). Archetypes of Strategy Formulation. Management Science. 24,253-280.

Nooraine,Mahmood (2008). Decision Magnitude of Impact Decision and Strategic Decision Magnitude of Impact and Strategic Decision Making Process Output. Journal Management Decision,46(4),640-655

Peteraf, MA, (1993). The Cornerstones of Competitive Advantage : A Resource-Based View. Strategic Management Journal; 14,(3),pp 179-191.

Porter.M.E. \& Kettels.C.H.M, (2003). UK Competitiveness: Moving to The Next Stage, DTI Economics No.3 ESRS

Penrose,E.T.(1959). The Theory of Growth of the Firm. New York: John Willey

Ramo, Laura. Guillen,(2009). The Impact of Social And Emotional Competencies On Effectiveness of Spanish Executives. Journal of Management Development, 28(9),771-793.

Surachman. (2007). Influence Skill Management and Business Orientation against Acceptance Rate Risk and Its Impact on Small Industries Product Development in East Java. Journal of Management Application.

Suci.R.P,(2009). Performance Improvement Through Entrepreneurial Orientation Management capabilities and Business Strategy ( Studies in smsll medium embroidery industries in East Java), www.researchgate.net.Jan2009

Stalk,G,Evans,P, \& Shulman,L,E (1992). Competing on Capabilities: The New Rules of Corporate Strategy, Harvard Business Review,70:57-69.

Suryana. (2003). Entrepreneurship Practical Guide, Tips and Process to Success. Salemba Four, Revised Edition.

Teece ,DJ, Pisano G, Amy Shuen,(1997). Dynamic Capabilities and Strategic Management Journal, Vol.18,No.7,hal 509-533.

Ulrich, D.(1997). Human Resource Champions: The Next Agenda for Adding Value and Delivering Result. Boston : Harvard Business School Press.

Wernerfelt,B,(1995). The Resource Based View of The Firm: Ten Years After. Strategic Management Journal. Vol.16, No.3, pages 171-174 